defined for values of $x$ and $y$ lying on the curve given by equations (1). The surface is singular and clearly not normal.

By considering the joint distribution of $x$ and $y+e$, where $e$ is a normally distributed 'error', independent of $x$ and $y$, we can obtain examples, with the properties indicated above, in which the joint distribution is non-singular.

The example bears on the use of tetrachoric $r$ as a 'metrical' measure of association between qualitative characters. What is assumed here is not merely that there exist separate metrical scales giving normal distribution separately to each of the hypothetical quantities supposed to underlie the given qualities. What is required is that the joint distribution of the hypothetical quantities be normal-a much stronger assumption.

Statistical Section,

S. P. VASWANI

Mathematics Department, Imperial College of Science and Technology, London, S.W.7.

\section{The Vienna Academy of Sciences}

IN his article on the Vienna Academy of Sciences, Dr. R. W. Lawson ${ }^{1}$ refers to the Biologische Versuchsanstalt and its distinguished directors. He does not mention E. Steinach, head of the Physiology Department and whom many biologists regard as the founder of modern endocrinology. Pincus ${ }^{2}$ and Sherrington ${ }^{3}$ refer to his work carried out during the long period 1898-1940. Steinach served as director from 1910 until 1938, when Austrian S.A. men invaded his estate and forced him to accept refuge in Switzerland, where he died about two years ago.

Steinach shared the great financial sacrifices that the directors had to make from their own pockets to maintain their laboratories. In the early twenties, inflation prevented the directors from continuing their donations, and the Academy lacking funds the Biologische Versuchsanstalt was about to close down. Just in time, however, the work done in Steinach's department attracted the interest of the Schering, A.G. A contract was arranged which enabled the Physiology Department to carry on, and on a much larger scale, the whole institute benefiting from the funds received.

The other directors referred to, H. Przibram and L. von Portheim, are now also dead, and I feel sure that they would be the very first to write this letter if they were still alive.

\section{Sunbury-on-Thames, \\ Middlesex.}

${ }^{1}$ Lawson, R. W., Nature, 159, 831 (1947).

"Pincus, G., "Recent Progress in Hormone Rescarch". Proceedings of the Laurentian Hormone Conference. (Academic Press, Inc., New York, 1947.)

"Sherrington, C.. "The Integrative Action of the Nervous System" (Cambridge Üniversity Press, 1947).

I CAN assure Dr. Peczenik that I had no intention of doing an injustice to any prominent member of the Vienna Biologische Versuchsanstalt in my recent article on the Vienna Academy of Sciences, and I am interested to learn of E. Steinach's valuable contributions on the physiological side of that institution's work during 1910-38.

As a physicist, I had no direct contact with the work of the "Vivarium" during my six years in
Vienna, and although $\Upsilon$ had a slight acquaintance with Hans Przibram, I was dependent for personal information primarily on an article by E. Broda and A. Stock ${ }^{1}$, who speak of the Versuchsanstalt (founded in 1901) as "the unique creation of Professor Hans Przibram". In the same publication (p. 10), Przibram's brother Karl writes of it as having been "founded conjointly with L. Portheim and W. Figdor by my late brother, Hans Przibram". "It was my brother's aim to make the Institute a centre not only of experimental, but also of 'quantitative' biology, and I hope this trend of research may be continued there, in memory of him who died a victim of Nazi barbarism." In his obituary notice on Leopold von Portheim, C. R. Metcalfe ${ }^{2}$ refers to the same three biologists as the founders of the Biologische Versuchsanstalt.

Perhaps I may be allowed to use this opportunity to correct a slight error in my article on the Vienna Academy. I had been given to understand that the physicist Karl Przibram had returned to work in the Vienna Radium Institute after the War. In a letter I have received from him recently, however, he informs me that he is now director of the Ir. Physik. alisches Institut of the University of Vienna. Prof. Karl Przibram is a worthy successor in the train of eminent physicists who have held that postFranz Exner, Gustav Jäger, and Egon von Schweidler. ROBERT W. LAWSON

"See p. 14 and p. 20 of the pamphlet entitled "Science in Austria", published in November 1945 by the Association of Austrian Engineers, Chemists, and Scientiflc Workers in Great Britain, London, W.2.

${ }^{2}$ Nature, 159, 835 (1947)

\section{Text-book Organic Chemistry}

We illustrate below by two examples certain elementary errors which have become imbedded in many text-books, with the result that some of the first facts of organic chemistry are being incorrectly presented to each succeeding group of students.

(1) The reaction between ethyl alcoholic potassium hydroxide and ethyl bromide, in fact, yields ether. Even if this be not generally known, the usual statement that it yields ethylene is inexcusable, for no one has ever shown that ethylene can thus be prepared in substantial yield ${ }^{1}$.

(2) The reaction between nitrous acid and methylamine yields mainly methyl nitrite. Being a gas, it goes away with the nitrogen, and hence has generally not been recognized; but that cannot justify the statement, for which no authority exists, that the main product is methyl alcohol. (Neither is it true that no methyl alcohol is formed, or that methyl ether is the main product ${ }^{2}$ )

It seems that the text-books have started a chain. reaction. They teach these stories to the students; whose examination papers by sheer repetition help to establish the said stories in the minds of the teachers, who then teach them to the next generation of students, whose examination papers ... This letter is intended as a chain-breaker.
A. T. Austin
E. D. HUGHES
C. K. INGOLD

Sir William Ramsay and Ralph Forster

Laboratories,

University College, London, W.C.1. June 3.

${ }^{1}$ Cf. Hughes, Ingold, Masterman and MacNulty, J. Ck:m. Soc., 899 (1940).

s Details of this reaction will be given in a forthcoming paper. 